\title{
Quantitative Estimation of Coastal Changes along Selected Locations of Karnataka, India: A GIS and Remote Sensing Approach
}

\author{
P. Vinayaraj, Glejin Johnson, G. Udhaba Dora, C. Sajiv Philip, V. Sanil Kumar, R. Gowthaman \\ Ocean Engineering Division, National Institute of Oceanography \\ (Council of Scientific \& Industrial Research), India \\ E-mail: sanil@nio.org \\ Received May 29, 2011; revised July 8, 2011; accepted August 29, 2011
}

\begin{abstract}
Qualitative and quantitative studies on changes of coastal geomorphology and shoreline of Karnataka, India have been carried out using toposheets of Survey of India and satellite imageries (IRS-P6 and IRS-1D). Changes during 30 years period are studied at each station. Significant morphological changes in landforms like spit, channel Island, coastal plain, tidal flat, lateritic plain, alluvial plain and sand bar within and adjacent to estuarine river mouths of Kali, Sharavathi, Kollur-Chakkara-Haladi and Udyavara Rivers are observed. The study indicates that gradual erosion is observed at i) Karwar spit along the northern side of the Kali river mouth, ii) the spit at the southern side of the Sharavathi river mouth and iii) at some regions of Kundapur.
\end{abstract}

Keywords: Coastal Geomorphology, Shoreline, Coastal zone, Erosion, Accretion, Beach

\section{Introduction}

Coastal zone is the transition area between land and ocean [1] and is an area of complex, dynamic and delicate environment. External factors influencing the coastal zone are the sediment supply by the rivers and coastal processes. Shoreline is one of the most rapidly changing landforms of the coastal zone. Geomorphic processes such as erosion, deposition, sedimentation, periodic storms, flooding and sea level changes are continuously modifying the shoreline. The accurate mapping of shoreline is therefore very important for planning conservation measures such as protection of human life, property and natural environment [2]. The coastal zone is receiving an increasing attention because of the pressure of increasing population and industrial developments. Erosion is also caused by shifting of river mouth and spits [3]. Protection of natural resources, the loss of habitats, severe coastal erosion, sedimentation in ports and harbors and municipal and industrial pollution are major concerns for coastal zone managers [4].

Remote sensing technology had been used commonly to map the shoreline and offers the potential of updating maps frequently [5]. Satellite Remote Sensing (RS) tech- nique has proved its utility in all fields of earth science studies including the study of coastal processes, because of the repetitive, synoptic and multispectral coverage's of the satellites. Satellite imageries are useful tools for detecting the coastal morphology changes. RS data can be used to evaluate the coastal processes like erosion/ accretion and shoreline changes. Geographic Information System (GIS) is designed to work with data referenced by spatial/geographical coordinates. The major advantage of GIS is that it allows identifying the spatial relationships between features and temporal changes within an area over time. Remote sensing satellites images have been effectively used for monitoring shoreline changes of different locations [6-8]. In this paper an attempt has been made to study the shoreline changes in terms of accretion, erosion and geomorphology using IRS-1D, IRS-P6, toposheets data and GIS technique along Karnataka coast, west coast of India.

\section{Study Area}

Karnataka coastline extends over a length of $280 \mathrm{Km}$ intercepted with a number of rivers joining the Arabian Sea. Areas near the river mouths along the coastline of Karnataka State suffer permanent erosion due to natural shifting 
and migration of the river mouths [9]. The present study focused at four regions; Karwar, Honnavar, Kundapur and
Malpe. Table 1 and Figure 1 present the location of beaches under study on either side of the river mouth.

Table 1. Location data of the study area.

\begin{tabular}{|c|c|c|c|}
\hline Stations & Starting Point & Ending Point & Distance (Km) \\
\hline Karwar (1) & $14^{\circ} 52^{\prime} 0^{\prime \prime} \mathrm{N} 74^{\circ} 6^{\prime} 0^{\prime \prime E}$ & $14^{\circ} 48^{\prime} 0^{\prime \prime} \mathrm{N} 74^{\circ} 8^{\prime} 0^{\prime \prime E}$ & 7.316 \\
\hline Honnavar (2) & $14^{\circ} 20^{\prime} 0^{\prime \prime} \mathrm{N} 74^{\circ} 23 ' 30^{\prime \prime} \mathrm{E}$ & $14^{\circ} 14^{\prime} 30^{\prime \prime N 74} 26^{\circ} 30^{\prime \prime E}$ & 10.002 \\
\hline Kundapur (3) & $13^{\circ} 40^{\prime} 0^{\prime \prime} \mathrm{N} 74^{\circ} 38^{\prime} 30^{\prime \prime} \mathrm{E}$ & $13^{\circ} 36^{\prime} 0^{\prime \prime N} 74^{\circ} 42^{\prime} 0^{\prime \prime} \mathrm{E}$ & 7.644 \\
\hline Malpe (4) & $13^{\circ} 22^{\prime} 0^{\prime \prime} \mathrm{N} 74^{\circ} 40^{\prime} 30^{\prime \prime} \mathrm{E}$ & $13^{\circ} 15^{\prime} 0^{\prime \prime} \mathrm{N} 74^{\circ} 44^{\prime} 0^{\prime \prime} \mathrm{E}$ & 14.383 \\
\hline
\end{tabular}

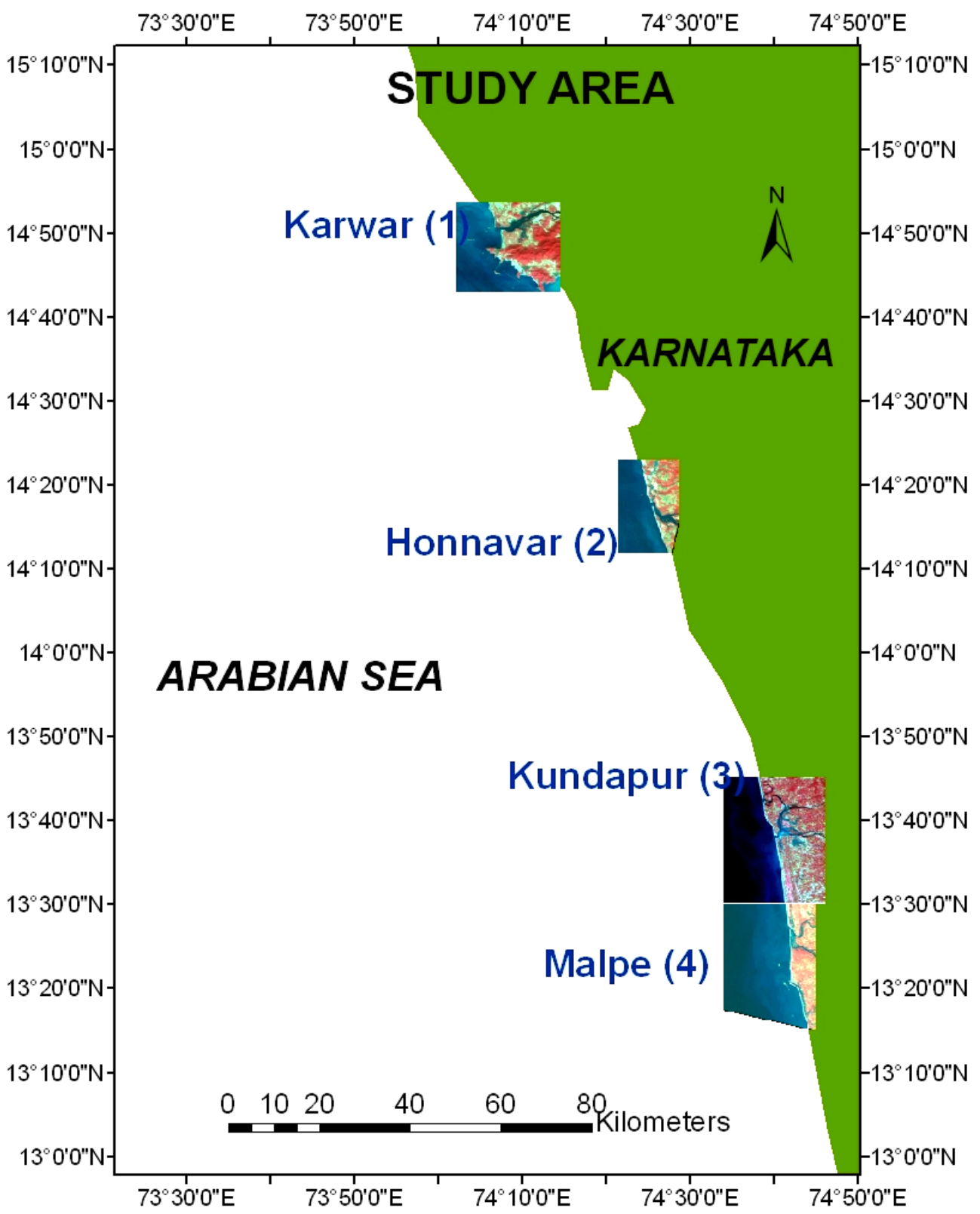

Figure 1. Location map of the study area. 
Karwar (station 1): Karwar is one of the major fishing zones in Karnataka. The Kali River flows through Karwar which is also a prominent tourist destination. The entire city of Karwar is situated on beach ridges formed due to the influence of Kali River and Arabian Sea confluence during the past [10]. The study area covers 7.316 $\mathrm{Km}$ and it covers north and south of the river mouth.

Honnavar (station 2): Shoreline covers $10.002 \mathrm{Km}$ and it lies on the banks of the river Sharavathi, forming an estuary in the central west coast of India. Honnavar is characterized by the presence of coastal alluvial soil, spit, lateritic plain and tidal flat.

Kundapur (station 3): Study area at this station covers 7.644 Km and is situated on the confluence of KollurChakkara and Haladi rivers and Arabian Sea. Rocky beaches, lateritic plain, alluvial plain, tidal flat and Channel Islands are the characteristics of Kundapur.

Malpe (station 4): Shoreline covers $14.383 \mathrm{Km}$ and it lies at the confluence of Udyavara river and Arabian Sea. Malpe is the largest fishing harbour in Karnataka. Rocky islands and barrier spit are the major characteristics of Malpe.

\section{Data and Methods}

\subsection{Data Source}

IRS-1D and IRS-P6, LISS-III (cloud free) satellite image of 26 Feb 19980547 hrs and 09 Jan 20080539 hrs, path 096 and row 062 covering the area between $74.1079^{\circ} \mathrm{E}$ and $74.728^{\circ} \mathrm{E}$ longitude and $14.87^{\circ} \mathrm{N}$ and $13.2608^{\circ} \mathrm{N}$ latitude was used for the study. IRS-1D and IRS-P6 are two among the series of Indian Remote Sensing satellites. Characteristics of both IRS-1D and IRS-P6 satellites are presented in Table 2.

\subsection{Data Processing}

Topomaps were scanned and opened in ERADAS IMAGINE 8.5 environment. Base maps were generated based on the Survey of India topographical maps surveyed in the year of 1973 for Kundapur, 1977 for Malpe, 1980 for Honnavar and 1981 for Karwar, registered by giving corner points after projecting into geographic projection with Modified Everest as the datum. IRS (LISS-III) imageries of 1998 and 2008 were Geo-registered with the base map using more than 25 corresponding Ground Control Points (GCPs) like bridges, road crossing and other permanent significant features, using survey of India toposheets [11].

Geo-registration is a process of stabilizing the relationship between map and the known real world coordinates. Re-sampling in each case was performed using cubic interpolation technique to keep the spatial distortions at minimum. Accuracy of the geo-correction is tested by swiping one image above the other and confirmed by field check. The geocorrected data is entered to the ArcGIS environment for digitization of shoreline. High waterline shown in the satellite imageries (1998 and 2008) and topographic sheets for all the four stations are digitized as line feature. Shorelines representing different years of a same station are presented by overlaying together. Quantification of erosion/accretion rate is done by digitization as polygon features using ArcGIS.

Coastal process are not uniform with respect to time and it is difficult to compare two scenes taken at different time because of the non-uniform tides of coastal area i.e., if it is low tide in one scene, it may be high tide in other one. So there is chance of error in estimation of erosion/accretion [10]. For minimizing the error, the data during similar tidal phase is considered in the present study.

Geomorphologic features like alluvial plain, tidal flat, sandbar, spit, rocky beaches and Channel Island are denoted on the imageries and plotted as geomorphologic maps for each station in different years.

\section{Results and Discussion}

The quantitative estimation of morphological changes along the shoreline and estuarine mouth of Karwar, Honnavar, Kundapur and Malpe are discussed below. The tide variation between the satellite imageries of 1998 and 2008 for the path/row-096-062 (Karwar and Honnavar) is negligible but path/row 097-063 (Kundapur and Malpe) shows $65 \mathrm{~cm}$ change in the tide between two data.

Table 2. Satellite data characteristics.

\begin{tabular}{|c|c|c|c|}
\hline Satellite & Sensors & Spectral bands(Microns) & Resolution (m) \\
\hline \multirow{3}{*}{ IRS-1D } & PAN & $0.50-0.75$ & 5.2 to 5.8 \\
\hline & LISS-III & $\begin{array}{c}0.52-0.59(\mathrm{~B} 2), \\
0.62-0.68(\mathrm{~B} 3), \\
0.77-0.86(\mathrm{~B} 4), \\
1.55-1.70(\mathrm{~B} 5)\end{array}$ & $\begin{array}{l}21.2 \text { to } 23.5 \\
(\mathrm{~V} \& \mathrm{IR})\end{array}$ \\
\hline & WiFS & 0.62 - 0.68 (Visible) & 169 to 188 \\
\hline \multirow{3}{*}{ IRS-P6 } & LISS-IV & $\begin{array}{c}0.52-0.59 \text { (Green (Band 2) } \\
0.62-0.68 \text { (Red (Band 3)) } \\
0.76-0.86 \text { (NIR (Band 4)) }\end{array}$ & 5.8 \\
\hline & LISS-III & $\begin{array}{l}0.52-0.59(\mathrm{~B} 2), \\
0.62-0.68(\mathrm{~B} 3), \\
0.77-0.86(\mathrm{~B} 4), \\
1.55-1.70(\mathrm{~B} 5)\end{array}$ & $\begin{array}{c}23.5 \\
(V \text { \& IR) }\end{array}$ \\
\hline & AWiFS & $\begin{array}{l}0.52-0.59 \\
0.62-0.68 \\
0.77-0.86 \\
1.55-1.70\end{array}$ & 58 \\
\hline
\end{tabular}


The erosion and accretion map of Karwar during the period of 1981 to 1998 (Figure 2) shows considerable erosion of around $1.459 \mathrm{Km}^{2}$ at the northern side of the Kali River along the shoreline. Net erosion during this period is $0.467 \mathrm{Km}^{2}$ and net accretion is $0.290 \mathrm{Km}^{2}$. The width of the river mouth has increased from 250 to 800 $\mathrm{m}$ without any significant change in the position of the river mouth, this is because of the erosion took place at the both banks of the river mouth. During the period from 1998 to 2008, at Karwar, erosion has occurred along the shoreline from the river mouth to the northern side to a length of around $3.75 \mathrm{Km}$ (Figure 2). It is also observed that the Kali River mouth has shifted slightly around $125 \mathrm{~m}$ towards north, with net erosion of $0.397 \mathrm{Km}^{2}$ and accretion of $0.102 \mathrm{Km}^{2}$ occurred during this period. The study indicates that an area of $0.405 \mathrm{Km}^{2}$ was eroded during the last 27 years (1981-2008) from the spit mouth, which is the most vulnerable location at station 1 .

The Sharavathi River mouth has shifted significantly (almost $1220 \mathrm{~m}$ ) towards north during the period between 1980 and 1998 (Figure 3). Northern side of the river mouth is affected by erosion and the southern side shows accretion. Net erosion and accretion of the station 2 (Honnavar) is $0.465 \mathrm{Km}^{2}$ and $0.631 \mathrm{Km}^{2}$ respectively. Most of the shoreline which lies along the southern part

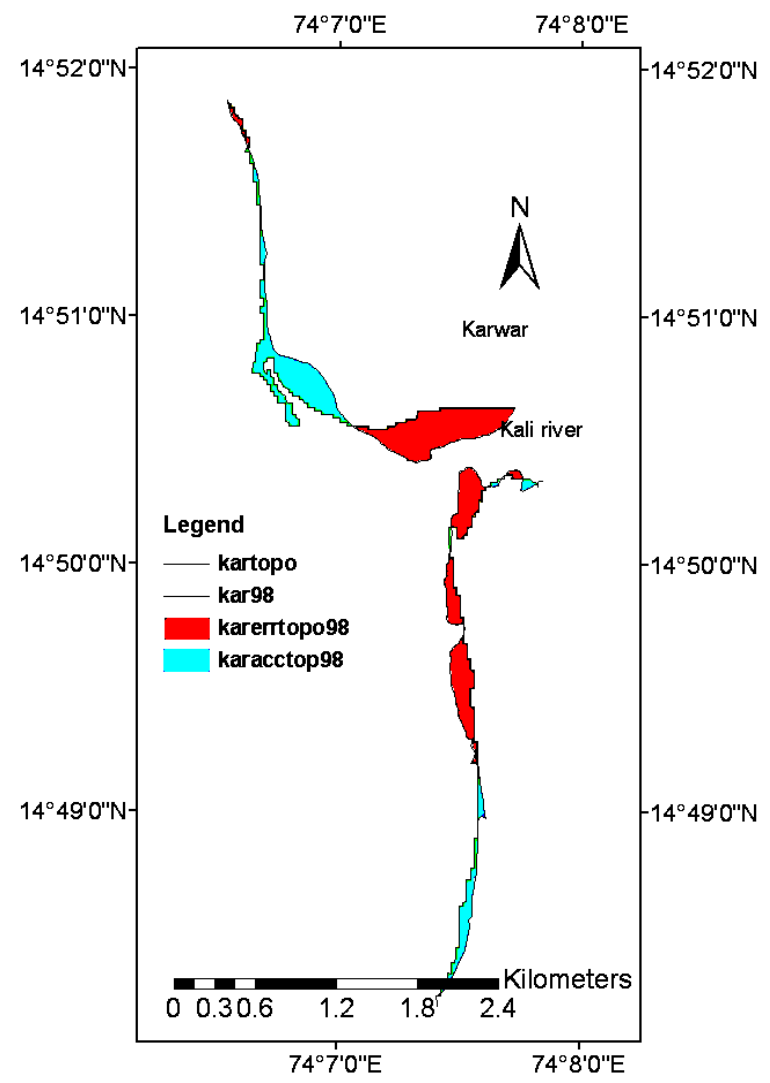

of the river mouth shows accretion. The width of the river mouth at Honnavar increased from 125 to $600 \mathrm{~m}$ during the ten year period from 1998 to 2008 because of the erosion at both edge of river mouth. Sediments from the tip of the spit on the southern side of river mouth, around $0.184 \mathrm{Km}^{2}$ areas washed off by erosion. Net erosion and accretion are measured as $0.383 \mathrm{Km}^{2}$ and 0.770 $\mathrm{Km}^{2}$. Study shows that during the last ten years (1998 2008) comparatively erosion is more than the accretion. Pavinkurve beach near the Basavarajadurg Island shows considerable erosion of $0.107 \mathrm{Km}^{2}$.

Erosion and accretion map of Kundapur during 1973 to 1998 , shows that river mouth has shifted around 270 $\mathrm{m}$ towards south (Figure 4). Erosion observed on the southern side of river mouth for almost $1.146 \mathrm{Km}$ along the shoreline.Net erosion and accretion of the area is $0.170 \mathrm{Km}^{2}$ and $0.326 \mathrm{Km}^{2}$ respectively. River mouth width decreased from 200 to $100 \mathrm{~m}$. Almost $2614 \mathrm{~m}$ along the shoreline of Gangoli beach grows seaward due to accretion. The width of the river mouth is considerably varying from 200 to $360 \mathrm{~m}$ during the last ten years from 1998 to 2008 because of the erosion of both side of the river mouth. An area $0.108 \mathrm{Km}^{2}$ of the entire shoreline of the station 3 got eroded. The net accretion of the area is around $0.127 \mathrm{Km}^{2}$.

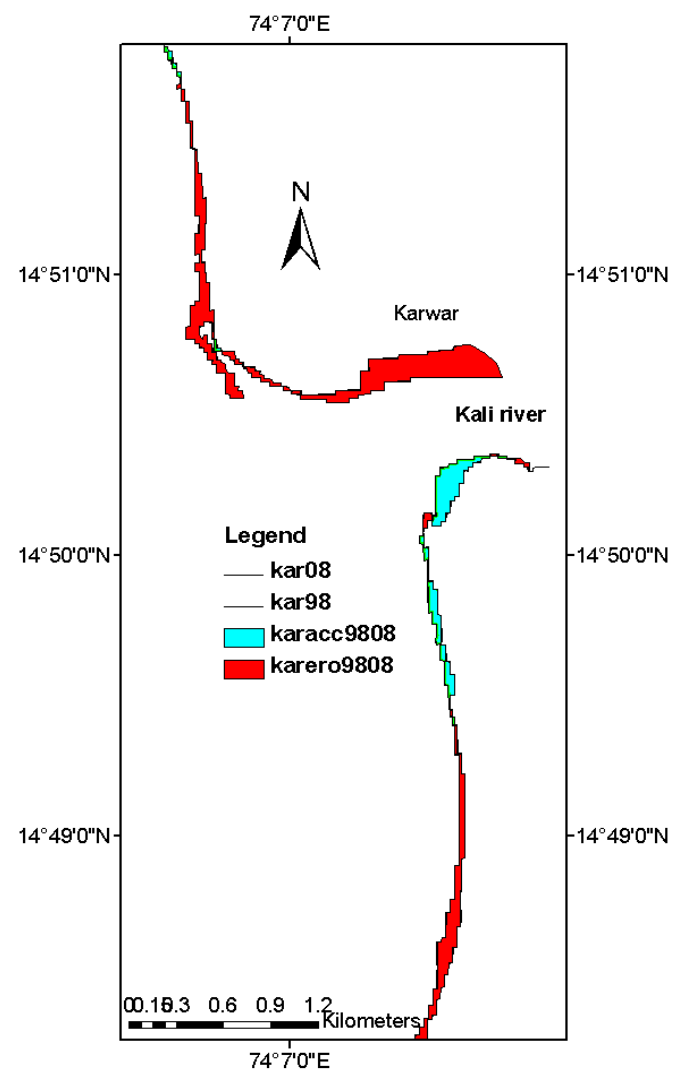

Figure 2. Erosion/accretion at Karwar during 1981-1998 and during 1998-2008. 

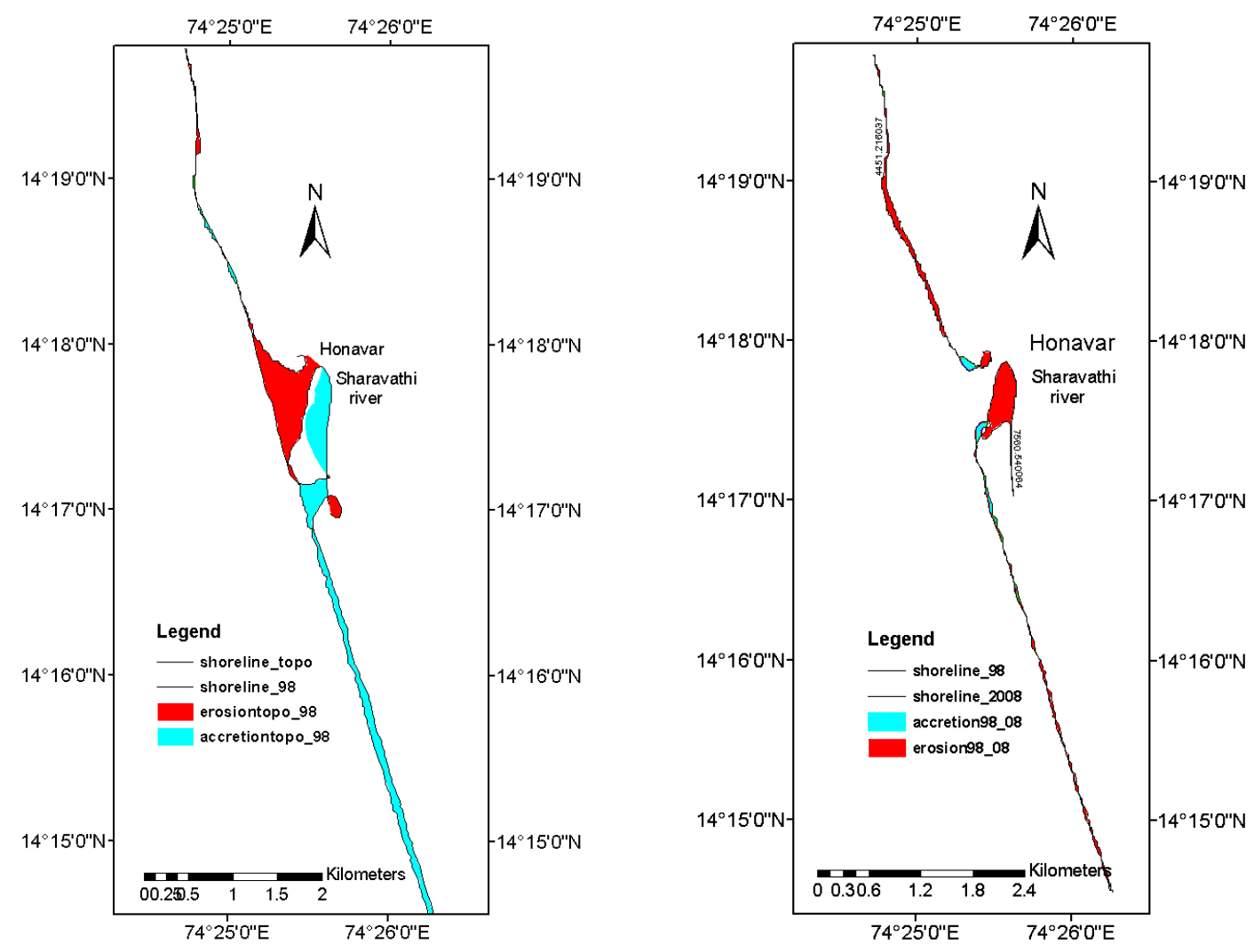

Figure 3. Erosion/accretion at Honnavar during 1979-1998 and during 1998-2008.
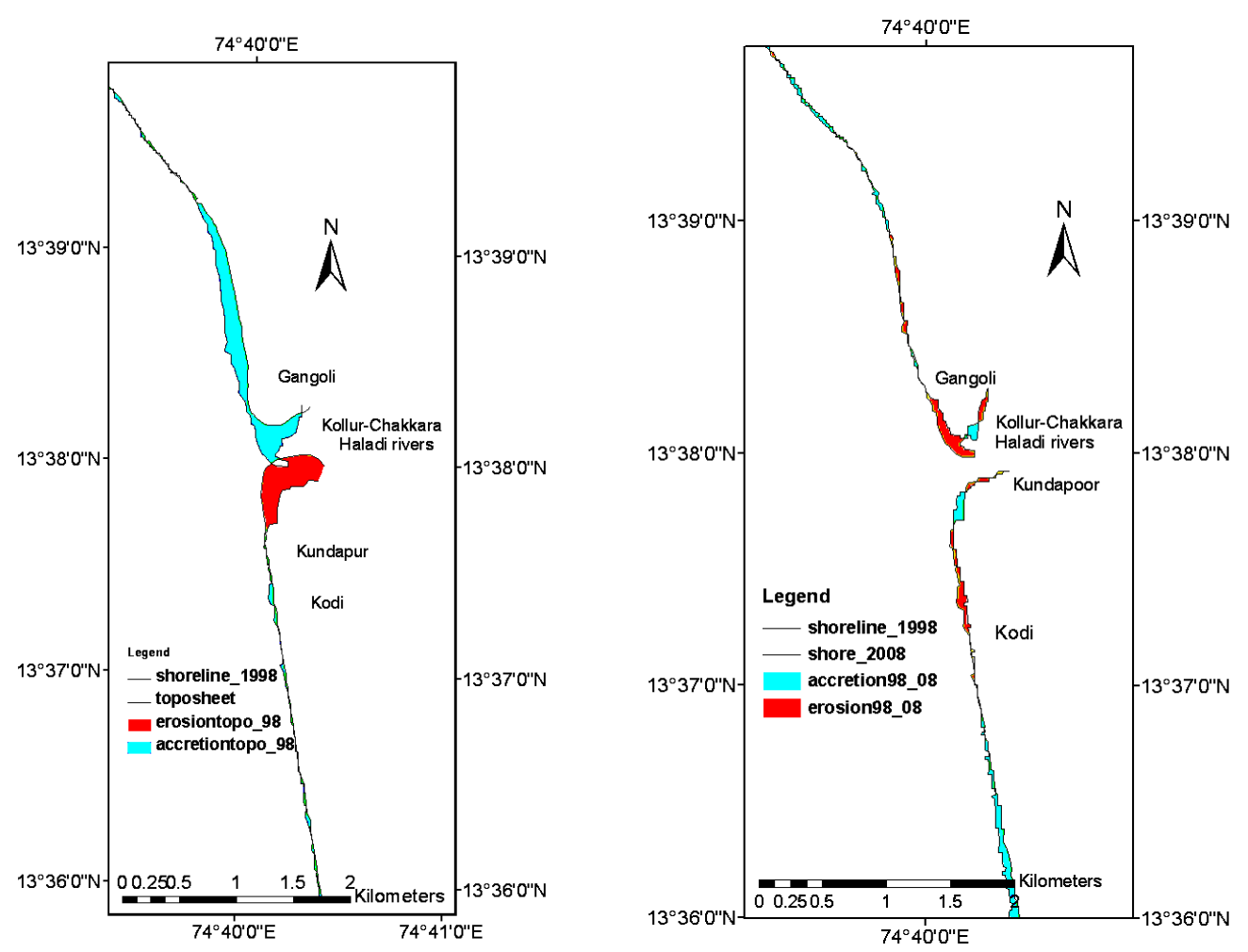

Figure 4. Erosion/accretion at Kundapur during 1973 - 1998 and during 1998 - 2008. 
Morphological changes near the Udyavara river estuary during the period from 1977 to 1998 (Figure 5) shows that width of the mouth has been decreased due to accretion on both sides of the river mouth from 200 to $100 \mathrm{~m}$. The tip of the barrier spit lies on the southern side of the river mouth grows gradually towards north-west direction, during 1977 to 1998 it has grown around 0.104 $\mathrm{Km}^{2}$. Net erosion and accretion of the area is $0.615 \mathrm{Km}^{2}$ and $0.192 \mathrm{Km}^{2}$ respectively. Study shows that, shoreline erosion is occurring along the locations at Tenkadiyur and Pangala to an extent of 1.372 and $4.636 \mathrm{Km}$ respecttively. During 1977 to 1998 an area of 0.113 and 0.368 $\mathrm{Km}^{2}$ were eroded from Tenkadiyur and Pangala respectively.

During 1998 to 2008, the width of the river mouth at Malpe reduced marginally from 260 to $224 \mathrm{~m}$. The tip of the barrier spit continued to grow towards north-west,

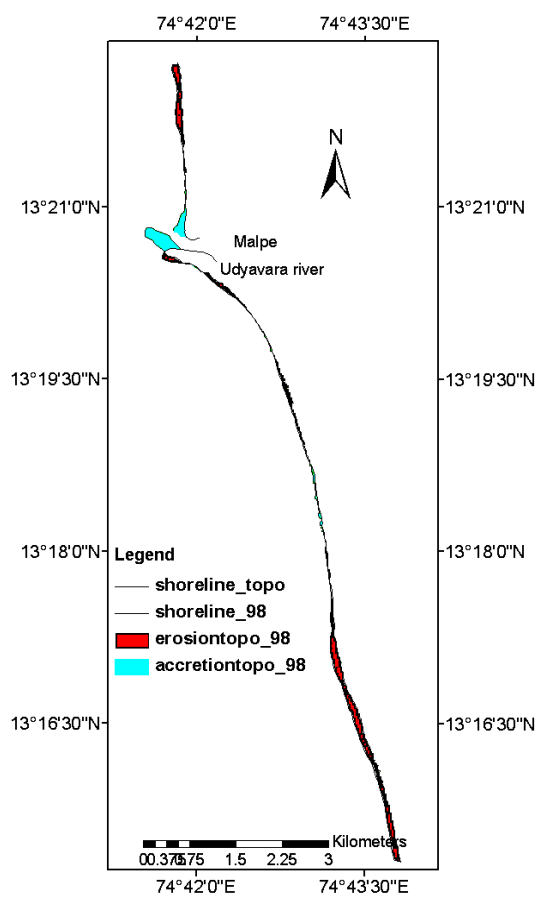

Figure 5. Erosion/accretion at Malpe during 1977-1998 and during 1998-2008. both side of the river mouth shows accretion. Only on the southern side of the river mouth, the spit got deposited around $0.035 \mathrm{Km}^{2}$. Study indicates that very small area is affected by erosion and most of the beach showed depositional characteristics. Net erosion of the area is 0.026 $\mathrm{Km}^{2}$ and the net accretion of the area is $0.355 \mathrm{Km}^{2}$. GIS and Remote Sensing approach study have been done by Dwarakish et al. [12] along the Malpe coastal region.

Karwar (1981-2008): The quantity measurement of the area covered by each geomorphology classes such as tidal flat, spit, Marine Island, sandy beach, creek, coastal plain, Channel Island and alluvial plain. Spit shows gradual decrease in the area. Among the various land form features spit shows the gradual decrease in area, 0.214 $\mathrm{Km}^{2}$ area got eroded from the mouth of the river Kali (Table 3). Slight increase observed in the area of coastal plain and alluvial plain. Creek has lost $1.028 \mathrm{Km}^{2}$.

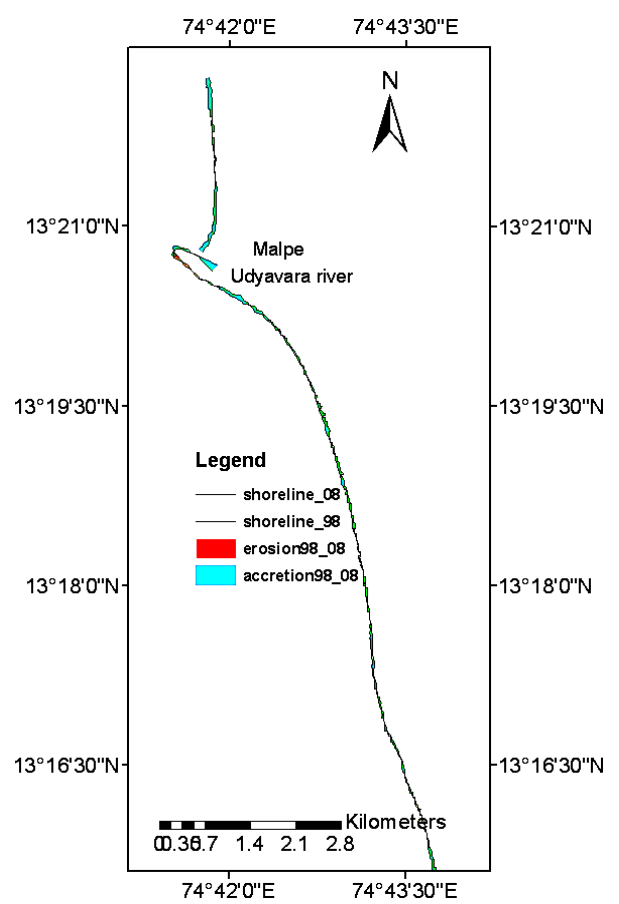

Table 3. Geomorphologic changes at Karwar.

\begin{tabular}{cccccc}
\hline Class & $\begin{array}{c}\text { Area }\left(\mathbf{K m}^{2}\right) \\
\mathbf{1 9 8 1}\end{array}$ & $\begin{array}{c}\text { Area }\left(\mathbf{K m}^{2}\right) \\
\mathbf{1 9 9 8}\end{array}$ & $\begin{array}{c}\text { Area }\left(\mathbf{K m}^{2}\right) \\
\mathbf{2 0 0 8}\end{array}$ & $\begin{array}{c}\text { Change in area }\left(\mathbf{K m}^{2}\right) \\
\mathbf{1 9 8 1 - 1 9 9 8}\end{array}$ & $\begin{array}{c}\text { Change in area }\left(\mathbf{K m}^{2}\right) \\
\mathbf{1 9 9 8 - 2 0 0 8}\end{array}$ \\
\hline tidal flat & 3.397 & 4.333 & 4.272 & 0.936 & -0.061 \\
spit & 0.814 & 0.729 & 0.601 & -0.085 & -0.128 \\
marine island & 0.187 & 0.187 & 0.187 & 0 & 0 \\
sandy beach & 0.505 & 0.622 & 0.513 & 0.117 & -0.109 \\
creek & 2.490 & 1.959 & 1.462 & -0.531 & -0.497 \\
coastal plain & 0.694 & 0.707 & 0.771 & 0.013 & 0.064 \\
channel island & 0.165 & 0.242 & 0.261 & 0.077 & 0.019 \\
alluvial plain & 16.187 & 16.389 & 17.091 & 0.202 & 0.702 \\
\hline
\end{tabular}


Honnavar (1980-2008): In the case of tidal flat, it is observed that $1.189 \mathrm{Km}^{2}$ area got reduced during the period 1980 to 1998 and an area of $0.542 \mathrm{Km}^{2}$ increased during 1998 to 2008.The spit which lies on the southern side of the Sharavathi river grows $0.370 \mathrm{Km}^{2}$ towards north (Table 4). Geomorphology of this area shows the presence and gradual decrease in the area of sand bars and creek. Marine Island and Lateritic plain do not show any observable change at the location. Coastal plain covers the maximum area of Honnavar region, coastal plain increase the area from 1980 to 1998 and after that it shows decreasing trend. In the case of Channel Island, it is showing an increasing trend in area from 1980 to 2008.

Kundapur (1973-2008): Rocky beach, sand bar and alluvial plane are the characteristics of Kundapur morphology. The area which covered by the tidal flat, decreased during 1973 to 1998 but $0.967 \mathrm{Km}^{2}$ area added during 1998 to 2008. Sand bar diminishes by an area of $0.227 \mathrm{Km}^{2}$ from 1973 to 1998, but after that it shows increasing trend from 1998 to 2008 (Table 5). No change can be detected in rocky beaches, marine Island and alluvial plain. It is detected that the coastal plain and channel Island gradually increases its area during 1973 to 1998. From 1998 to 2008, coastal plain area increased by 0.159 $\mathrm{Km}^{2}$, but Channel Island shows a slight reduction in area from 1998 to 2008. Jayappa et al., [13] studied the area through remote sensing.

Malpe (1977-2008): It is noticed that most of the study area of Malpe is covered by coastal plain, it shows some changes in the area too. Barrier spit on the southern side of the river mouth detected as increasing during 1998 to 2008 and decrease in area of $0.190 \mathrm{Km}^{2}$ from 1977 to 1998 (Table 6). Area covered by creek reduced during the study period. Overall sand bar quantity increased during the study period. It is observed that the Channel Island of $0.055 \mathrm{Km}^{2}$ diminished.

Table 4. Geomorphologic changes at honnavar.

\begin{tabular}{cccccc}
\hline Class & $\begin{array}{c}\text { Area Km } \\
\mathbf{1 9 7 9}\end{array}$ & $\begin{array}{c}\text { Area } \mathbf{K m}^{2} \\
\mathbf{1 9 9 8}\end{array}$ & $\begin{array}{c}\text { Area } \mathbf{K m}^{2} \\
\mathbf{2 0 0 8}\end{array}$ & $\begin{array}{c}\text { Change in area } \mathbf{K m}^{2} \\
\mathbf{1 9 7 9 - 1 9 9 8}\end{array}$ & $\begin{array}{c}\mathbf{C h a n g e ~ i n ~ a r e a ~ K m ~}^{2} \\
\mathbf{1 9 9 8 - 2 0 0 8}\end{array}$ \\
\hline tidal flat & 2.085 & 0.896 & 1.438 & -1.189 & 0.542 \\
spit & 1.515 & 1.886 & 1.819 & 0.371 & -0.067 \\
sandy beach & 0.955 & 0.945 & 1.020 & -0.01 & -0.075 \\
sand bar & 0.023 & 0.083 & 0.040 & 0.060 & 0.002 \\
marine island & 0.202 & 0.164 & 0.166 & -0.038 & 0 \\
lateritic plain & 16.956 & 16.956 & 16.956 & 0 & -0.016 \\
creek & 1.135 & 0.592 & 0.576 & -0.543 & -0.679 \\
coastal plain & 11.728 & 12.004 & 11.325 & 0.276 & 0.171 \\
channel island & 0.995 & 1.166 & 1.272 & 0.106 \\
\hline
\end{tabular}

Table 5. Geomorphologic changes at Kundapura.

\begin{tabular}{|c|c|c|c|c|c|}
\hline Class & $\begin{array}{l}\text { Area }\left(\mathrm{Km}^{2}\right) \\
\quad 1973\end{array}$ & $\begin{array}{c}\text { Area }\left(\mathrm{Km}^{2}\right) \\
1998\end{array}$ & $\begin{array}{l}\text { Area }\left(\mathrm{Km}^{2}\right) \\
\quad 2008\end{array}$ & $\begin{array}{c}\text { Change in area }\left(\mathrm{Km}^{2}\right) \\
1979-1998\end{array}$ & $\begin{array}{c}\text { Change in area }\left(\mathrm{Km}^{2}\right) \\
1998-2008\end{array}$ \\
\hline tidal flat & 2.581 & 2.050 & 3.018 & -0.531 & 0.968 \\
\hline sand bar & 0.296 & 0.069 & 1.083 & -0.227 & 1.014 \\
\hline sandy beach & 0.637 & 0.703 & 0.676 & 0.066 & -0.027 \\
\hline rocky beach & 0.027 & 0.027 & 0.027 & 0 & 0 \\
\hline marine island & 0.052 & 0.052 & 0.052 & 0 & 0 \\
\hline lateritic plain & 2.805 & 2.805 & 2.805 & 0 & 0 \\
\hline coastal plain & 10.363 & 10.823 & 11.018 & 0.460 & 0.195 \\
\hline channel island & 3.512 & 4.140 & 4.105 & 0.628 & -0.035 \\
\hline alluvial plain & 0.743 & 0.743 & 0.743 & 0 & 0 \\
\hline
\end{tabular}


Table 6. Geomorphologic changes at malpe.

\begin{tabular}{|c|c|c|c|c|c|}
\hline Class & $\begin{array}{c}\text { Area }\left(\mathbf{K m}^{2}\right) \\
1977\end{array}$ & $\begin{array}{c}\text { Area }\left(\mathrm{Km}^{2}\right) \\
1998\end{array}$ & $\begin{array}{l}\text { Area Km}^{2} \\
2008\end{array}$ & $\begin{array}{c}\text { Change in area } \mathrm{Km}^{2} \\
1979-1998\end{array}$ & $\begin{array}{c}\text { Change in area } \mathrm{Km}^{2} \\
1998-2008\end{array}$ \\
\hline sandy beach & 1.123 & 0.978 & 1.267 & -0.145 & 0.289 \\
\hline sand bar & 0.307 & 0.204 & 0.362 & -0.103 & 0.158 \\
\hline marine island & 0.555 & 0.555 & 0.555 & 0 & 0 \\
\hline creek & 0.689 & 0.420 & 0.320 & -0.269 & -0.100 \\
\hline coastal plain & 23.318 & 23.168 & 23.440 & -0.150 & 0.272 \\
\hline channel island & 0.340 & 0.246 & 0.285 & -0.094 & 0.039 \\
\hline barrier spit & 1.002 & 0.812 & 0.938 & -0.190 & 0.126 \\
\hline
\end{tabular}

\section{Conclusions}

This study investigates the coastal erosion and deposition at four stations (Karwar, Honnavar, Kundapur, and Malpe) covering a period of almost thirty years along the Karnataka, west coast of India. Both erosion and deposition are observed at all the four stations. The erosion observed is not continuous all along the coast but in isolated stretches along the coast. Comparatively large erosion have been observed at the river mouths of Devbag (north of Kali River), at Pavinakurve (north of Sharavathi River) and at Kundapur. The coastline at Malpe is almost stable with negligible erosion and deposition. Significant amount of loss of land is observed mainly at the river mouth due to the sediment erosion from the banks because of complex interactions between river flow, waves and the tides.

\section{Acknowledgements}

We thank Integrated Coastal and Marine Area Management Project Directorate (ICMAM PD), Ministry of Earth Sciences, New Delhi for funding the project. Director, National Institute of Oceanography, Goa and Project Director, ICMAM PD, Chennai for the encouragement provided to carry out the study. This is NIO contribution 4995.

\section{References}

[1] M. M. Aidy, M. F. Giles and P. M. Atkinson, "Shoreline Mapping from Coarse-Spatial Resolution Remote Sensing Imagery of Seberang Takir, Malaysia,” Journal of Coastal Research, Vol. 23, No. 6, 2007, pp. 1399-1408.

[2] N. Tirkey, R. S. Biradar, M. Pikle and S. Charatkar, “A Study on Shoreline Changes of Mumbai Coast Using ReMote Sensing and GIS," Journal of Indian Society of Remote Sensing, Vol. 33, No. 1, 2005, pp. 85-91. doi:10.1007/BF02989995
[3] P. V. Vijayan, G. Bhat and M. S. Vinaya, "Long Term Morphological Changes of Shoreline and Estuaries along the Northern Kerala Coast-Remote Sensing and GIS Based Study,” In: K. S. Jayappa and A. C. Narayana, Eds., Coastal Environmental Problems and Perspectives, I.K. international Publishing House Pvt. Ltd., New Delhi, 2009, pp. 96-107.

[4] S. Nayak, "Use of Satellite Data in Coastal Mapping,” 2002. http://www.incaindia.org/technicalpapers/24_CMMC01.pdf

[5] O. E. Frihy and M. F. Lofty, "Shoreline Changes and Beach Sand Sorting along the Northern Sinai Coast of Egypt,” Geo-Marine Letters, Vol. 17, No. 2, 1997, pp. 140-146. doi:10.1007/s003670050019

[6] P. P. Rao, M. M. Nair and D. V. Raju, "Assesment of the Role of Remote Sensing Techniques in Monitoring Shoreline Changes: A Case Study of Kerala Coast," International Journal of Remote Sensing, Vol. 6, No. 3-4, 1984, pp. 549-558.

[7] A. S. Rajawat, M. Gupta, Y. Pradhan, A. V. Thomsakutty and S. Nayak, "Coastal Process along the Indian CoastCase Studies Based on Synergistic Use of IRS-P4 and OCM and IRS-1C/1D data," Indian Journal of Marine Science, Vol. 34, No. 4, 2005, pp. 459-472.

[8] A. A. Aleshelkh, A. Ghorbanall and N. Nouri, "CoastLine Change Detection Using Remote Sensing,” International Journal of Environmental Science and Technology, Vol. 4, No. 1, 2007, pp. 61-66.

[9] J. Dattatri, "Coastal Erosion and Protection along Karnataka Coast," Centre for Environmental Law, Education, Research and Advocacy (CEERA), The National Law School of India University, 2007. http://www. nlsenlaw.org/live/nlsenlaw/crz/articles

[10] T. Hanamgond and D. Mitra, "Dynamics of the Karwar Coast, India, with Special Reference to Study of Tectonics and Coastal Evolution Using Remote Sensing,” Journal of Coastal Research, Vol. 50, 2007, pp. 842-847.

[11] E. P. Nobi, A. Shivaprasad, R. Kaikalan, E. Dilipan, T. Thangaradjou and K. Shivakumar, "Micro Level Mapping of Coastal Geomorphology and Coastal Resources of Rameswaram, India-A Remote Sensing and GIS 
perspective,” Journal of Coastal Research, Vol. 26, No. 3, 2010, pp. 424-428. doi:10.2112/08-1119.1

[12] G. S. Dwarakish, S. A. Vinay, U. Natesan, T. Asano, T. Kakinuma, K. Venkitaramana, B. Jagadeesh Pai and M. K. Babitha, "Coastal Vulnerability Assessment of the Future Sea Level Rise in Udupi Coastal zone of Karnataka State, west Coast of India,” Ocean and Coastal Management, Vol. 52, No. 9, 2009, pp. 467-468. doi:10.1016/j.ocecoaman.2009.07.007

[13] V. K. Jayappa and A. Kumar, "Evolution of Coastal Landforms, Southern Karnataka-A Remote Sensing Approach,” In: K. S. Jayappa and A. C. Narayana, Eds., Coastal Environmental Problems and Perspectives, I.K. international Publishing House Pvt. Ltd., New Delhi, 2009, pp. 79-96. 